Klinička psihologija 12 (2019), 1-2, 21-38

Izvorni znanstveni rad - UDK

DOI: 10.21465/2019-KP-1-2-0002

\title{
NEKI PREDIKTORI DEPRESIVNOSTI U ADOLESCENCIJI
}

\author{
Katarina Jelić \\ Udruga Pragma \\ Teslina 13, 10000 Zagreb \\ jelic@udruga-pragma.hr
}

\begin{abstract}
Sažetak
Depresija je složeni psihološki konstrukt koji tumačimo pomoću brojnih faktora. Vjerojatnost doživljavanja depresivnih simptoma dvostruko je veća za žene, a razlike s obzirom na spol pojavljuju se upravo u adolescenciji kada kod oba spola dolazi do porasta u depresivnosti. Ovakvi nalazi potvrđeni su u ovom istraživanju na uzorku učenika srednjih škola $(\mathrm{N}=335)$ u kojem su depresivni simptomi mjereni Skalom depresivnosti za djecu i adolescente (Vulić-Prtorić, 2003).

Depresivnost se na predstavljenome uzorku nastojala objasniti hijerarhijskim modelom koji je kombinirao jedinstveni doprinos varijabli dobi, spola, roditeljskog stila odgoja i perfekcionizma kod adolescenata. Tako pretpostavljeni model uspio je objasniti ukupno $43 \%$ varijance depresivnosti na odabranome uzorku.

Autoritativni stil odgoja dosljedno se povezuje s psihološkom dobrobiti djece, dok je autoritarni povezan s brojnim internaliziranim problemima kao što je depresivnost. To objašnjava značajne i visoke korelacije između rezultata na Skali percepcije roditeljskog ponašanja (Macuka, 2008) s depresivnošću, ali i mjerama perfekcionizma na uzorku adolescenata. Perfekcionizam se definira u terminima postavljanja visokih standarda, uz pretjerano kritične samoevaluacije. U adolescenciji se naglašava izvedba, što u kombinaciji s brojim drugim promjenama čini pojedinca ranjivim za razvoj depresije, na što upućuje i dobivena povezanost rezultata na Multidimenzionalnoj skali perfekcionizma (MPS-F) i depresivnosti.
\end{abstract}

Ključne riječi: adolescencija, depresivnost, perfekcionizam, roditeljstvo

\section{UVOD}

Depresija se spominje u svim kulturama i povijesnim razdobljima. Upravo se početak 21. stoljeća često opisivao kao period istaknute depresivnosti (Vulić-Prtorić, 2004). Smatra se najčešćim psihijatrijskim poremećajem koji se uglavnom pojavljuje tijekom adolescencije, a liječenje može biti otežano i dugotrajno. Rizik obolijevanja žena procjenjuje se na 10-25\%, a muškaraca 5-12\% (Begić, 2014). 
Prema podacima HZJZ-a gotovo $26 \%$ svih mentalnih poremećaja u RH odnose se na depresivne poremećaje, a u 2017. godini bili su jedan od vodećih razloga hospitalizacije djece $u$ dobi 10-19 godina.

Prema DSM-u-5 (Američka psihijatrijska udruga, 2014), najčešći simptomi depresivnosti kod djece su somatske pritužbe i razdražljivost, iako postoje određene spolne razlike u smislu da djevojčice manifestiraju više negativnih raspoloženja, dok se kod dječaka pojavljuju problemi u ponašanju. Kod adolescenata se u oko $80 \%$ slučajeva uz žalost pojavljuje i snažna ljutnja (Vulić-Prtorić, 2004).

Depresivnost adolescenata neugodno je iskustvo za sve članove obitelji. Porast depresivnosti u toj dobi uvelike je povezan s biološkim promjenama i razvojem apstraktnoga mišljenja (Berk, 2007). Spolne razlike u depresivnosti tumače se kombinacijom hormonalnih promjena i okolinskih faktora kao što su stresni životni događaji, spolno tipiziranje itd. Djevojčice su podložnije pritiscima iz okoline jer im samopoštovanje u većoj mjeri ovisi o socijalnim odnosima za razliku od dječaka koji više vrjednuju postignuća (Seligman, 2005; 2006). Također, žene su u prosjeku sklonije depresivnom kognitivnom stilu i ruminaciji (Vulić-Prtorić, 2004).

Sistemska teorija depresiju povezuje s roditeljskim nerealnim očekivanjima, sklonosti kritiziranju djece te usmjerenosti na neuspjeh. Nejasno je potiče li stil odgoja depresivnost ili je ona posljedica narušenih obiteljskih odnosa i učestalih sukoba. Budući da obiteljski kontekst obiluje rizičnim i zaštitnim faktorima za razvojni put depresije, istraživanja su često usmjerena na varijable koje zahvaćaju obiteljsku dinamiku. Primjerice, pokazalo se kako je komunikacija u obiteljima depresivne djece obilježena ljutnjom i odbacivanjem (Jin, 2014), dok Sander i McCarthy (2005) kao glavne rizične faktore za razvoj depresivnosti adolescenata navode toplinu i prihvaćenost od strane roditelja, njihov kognitivni stil, obiteljsku emocionalnu klimu i koheziju. Slično, Kurtović (2012) navodi kako su obiteljski odnosi depresivne djece $\mathrm{i}$ adolescenata obilježeni sukobima, a negativni roditeljski postupci dugoročno mogu utjecati na kognitivni stil i samopoštovanje djece. Kognitivnu trijadu depresije čine pesimistično doživljavanje sebe, drugih i budućnosti. Alternativno tumačenje nudi psihoanalitička teorija prema kojoj je depresija povezana s oralnim tipom ličnosti, fiksacijom na iskustvo bespomoćnosti, potisnutom agresijom i narcizmom.

Filozofija odgoja tijekom vremena varirala je između restriktivnog odgoja koji za cilj ima poslušnost djece te permisivnog koji naglašava njihovo zadovoljstvo i sreću. Pokušaji grupiranja različitih roditeljskih postupaka rezultirali su dimenzionalnim pristupom proučavanju roditeljstva, gdje većina autora naglašava dvije glavne dimenzije roditeljstva koje su relativno stabilne u svim razvojnim periodima. Dimenzija emocionalnosti obuhvaća postupke duž kontinuuma od iskazivanja hladnoće, udaljenosti, odbacivanja djeteta i hostilnosti do topline, brige i prihvaćanja djeteta. Za razvoj depresivnosti posebno je rizična tzv. psihološka kontrola, odnosno postupci koji za cilj imaju učiniti dijete emocionalno zavisnim o roditelju i sprječavanje razvoja dječje samostalnosti. Ovakav oblik kontrole svojstven je autoritarnom 
stilu odgoja te narušava psihički i emocionalni razvoj djeteta. Autoritarni roditelji su izrazito visoko na dimenziji kontrole, uz nisko prihvaćanje i toplinu. Premda njihova djeca možda iskazuju manje nepoželjnog ponašanja poput ovisnosti i markiranja, u isto vrijeme se češće konformiraju, imaju nisko samopoštovanje, izražene probleme u odnosima te su ujedno sklonija depresivnosti.

Perfekcionizam (lat. Perficere, što znači ostvariti, dovršiti) kao pojam stariji je od suvremene psihologije. Nakon dugog perioda u kojemu se pretpostavljalo kako se radi o izrazito negativnoj osobini, takav stav konačno je doveden u pitanje kada su započela sustavna znanstvena istraživanja. Flett i Hewitt (2002) definiraju perfekcionizam u terminima težnje za nepogrešivosti u svim sferama života. Shafran (2002) je zagovarao jednodimenzionalni pristup prema kojemu je perfekcionizam negativna osobina. Iako navedenu tezu potkrjepljuju rezultati dobiveni na populaciji kliničkih perfekcionista, kasnije je postalo jasno kako samo jedna dimenzija ne može dovoljno dobro objasniti različite aspekte konstrukta, stoga su Frost, Marten, Lahart i Rosenblate (1990) predložili ukupno 6 dimenzija perfekcionizma. To su redom: visoki osobni standardi, zabrinutost oko pogrešaka u izvedbi, sumnja u kvalitetu izvedbe, naglašavanje reda, preciznost i organizacija te očekivanja i kritike od strane roditelja. Njihov rad rezultirao je konstruiranjem skale za mjerenje višedimenzionalnoga perfekcionizma (MPS-F) na kojima su faktorskom analizom ekstrahirana dva nadređena faktora - pozitivne težnje i neadaptivna briga - a dodatnom analizom utvrđeno je kako navedeni faktori zajedno objašnjavaju oko 67\% varijance konstrukta.

Osim utvrđivanja dimenzija koje su u osnovi perfekcionizma, jednako je važno pitanje njegova etiologija. Autori se uglavnom slažu oko toga da je za razvoj perfekcionizma ključno razdoblje djetinjstva i adolescencije. Longitudinalna istraživanja pokazuju kako djeca često zamijene inicijalno zdravi perfekcionizam za maladaptivni u dobi od 4 godine (Parker i Adkins, 1995). Roditeljski stil, nerealna i visoka očekivanja stvaraju snažan pritisak na izvedbu, stoga njihova djeca razvijaju maladaptivni perfekcionizam, odnosno opravdano je pretpostaviti kako postoji veza između perfekcionizma te autoritarnog stila odgoja. Primjerice, Oros, Iuorno i Serppe (2017) utvrdili su kako se dječji perfekcionizam može povezati s pretjeranom kontrolom te zahtjevima od strane roditelja, ali i depresijom.

Prema modelu socijalnih očekivanja, djeca od malena uče kako trebaju zadovoljiti određene standarde da bi zadobila ljubav roditelja. U situaciji kada roditelji ne postavljaju nikakve standarde, djeca to čine umjesto njih. Međutim, takvi ciljevi često su nerealistični i razvojno neprimjereni te povezani s patološkim razvojnim ishodima. Primjerice, povezanost uvjetovanog osjećaja samopoštovanja, negativnog perfekcionizma i depresije potvrđena je korelacijskim istraživanjem DiBartola, Yena i Frosta (2008).

Model socijalnog učenja pretpostavlja kako se perfekcionizam razvija na osnovi imitiranja ponašanja roditelja. Chang (2000) izvještava o značajnoj povezanosti perfekcionizma roditelja i djece, no nije sasvim jasno je li ta povezanost posljedica 
utjecaja gena ili modeliranja. Model socijalne reakcije tumači perfekcionizam u svjetlu nepovoljnih životnih događaja i uvjeta kao što su zlostavljanje, emocionalna hladnoća ili posramljivanje, pa je prema tome modelu perfekcionizam posljedica nastojanja pojedinca da izbjegne buduće zlostavljanje i pokuša kontrolirati neizvjesnu okolinu. Posljednji model razmatra utjecaj izražene anksioznosti roditelja zbog čega su skloniji upozoravati djecu na moguće pogreške i potencijalno osuđivati ponašanja koja im izazivaju anksioznost.

Pozitivni aspekti perfekcionizma traženi su i poželjni, a u istraživanjima često koreliraju sa savjesnosti koja je dobar prediktor sebi usmjerenoga perfekcionizma (Stoeber, Otto i Dalbert, 2009). No, negativne dimenzije perfekcionizma povezane su s brojnim psihičkim teškoćama. Posebno je zanimljiva prediktivna vrijednost za depresiju koju su davno već dokazali Frost i suradnici (1990) te Hewitt i Flett (1991), ujedno jedni od najproduktivnijih autora iz toga područja. U istraživanjima je utvrđeno kako se depresija na osobit način može povezati s dimenzijom zabrinutosti zbog pogrešaka (Belavić, 2006) i općenito samokritičnosti koja ponajviše pogađa mlade osobe opterećene imidžom, pitanjem identiteta i nastojanjem zadobivanja prihvaćanja od strane vršnjaka. Iskustvo adolescencije je stresno, ali je isto tako velik izazov za istraživače i stručnjake budući da su individualne varijacije veće nego ikada (Hwang i Nilsson, 2000). Zbog svih navedenih zaključaka o povezanosti ponašanja roditelja s internaliziranim problemima adolescenata te onoga što je do sada poznato o etiologiji perfekcionizma, cilj ovoga istraživanja odnosi se na utvrđivanje doprinosa mjera perfekcionizma i stilova roditeljstva tumačenju pojave depresivnosti kod adolescenata.

\section{METODA}

\section{Sudionici}

Ispitivanjem su bili obuhvaćeni učenici srednjih škola, s rasponom dobi od 15 do 18 godina. Nakon eliminiranja nedovršenih i neispravnih upitnika, uzorak je sačinjavalo sveukupno 335 učenika, odnosno 118 dječaka (35,22\%) i 217 djevojčica (64,78\%). Detalji su vidljivi u Tablici 1.

\section{Postupak}

Instrumenti su primijenjeni na razrednim skupinama 12-25 učenika, anonimno te uz dobrovoljni pristanak učenika i dozvolu ravnatelja. Prije početka ispitivanja učenicima je ukratko i na razumljiv način objašnjena svrha ispitivanja te navedeno u koju će se svrhu koristiti dobiveni rezultati. Prije same primjene instrumenata pružena im je specifična uputa o načinu odgovaranja. Dodatna objašnjenja pružena su individualno, prema potrebi. 





Mjerni instrumenti

Skala percepcije roditeljskog ponašanja (SPRP): skala (Macuka, 2008) sadrži 25 čestica koje zahvaćaju ponašanja roditelja, odnosno osnovne dimenzije roditeljskog ponašanja - emocionalnost i kontrolu. Zadatak sudionika je na skali od 3 stupnja odabrati odgovor koji najbolje opisuje ponašanja njihovih roditelja. Sadrži tri subskale (Prihvaćanje, Odbacivanje i Kontrola). Preporuča se primjena na uzorcima djece u dobi 10-18 godina, a ukupan rezultat dobiva se zbrajanjem procjena na pojedinačnim tvrdnjama. Prilikom primjene eksploratorne faktorske analize potvrđena je trofaktorska struktura. Valjanost je potvrđena korelacijama između rezultata na subskalama SPRP i CRPBI-57 skale. Što se pouzdanosti tiče, koeficijenti unutarnje konzistencije su također zadovoljavajući, s Cronbach alpha vrijednostima koje variraju 0,71-0,95.

Skala depresivnosti za djecu i adolescente (SDD): skala za mjerenje depresivnosti (Vulić-Prtorić, 2003) sastoji se od 26 čestica koje opisuju najčešće simptome depresivnosti u djetinjstvu i adolescenciji. Tvrdnje su odabrane na osnovi popisa simptoma iz DSM-5 klasifikacije, s obzirom na različita psihodijagnostička sredstva i na temelju rezultata brojnih istraživanja. Za svaku tvrdnju ponuđen je odgovor na skali Likertova tipa od 5 stupnjeva. Skala je namijenjena ispitanicima u dobi 10-18 godina. Ocjenjivanje odgovora je objektivno, a ukupan rezultat dobiva se zbrajanjem procjena na svim česticama. Na uzorku od preko 2500 ispitanika kronološke dobi 10-18 godina dobivena je unutrašnja pouzdanost tipa Cronbach alpha od 0,895. Osjetljivost skale je zadovoljavajuća, što je čini pogodnom za korištenje u znanstveno-istraživačke svrhe.

Multidimenzionalna skala perfekcionizma (MPS-F): Zubčić i Vulić-Prtorić (2008) adaptirale su originalnu Frostovu skalu, koja se sastoji od 35 tvrdnji te mjeri perfekcionizam kroz ukupno šest dimenzija: Osobni standardi, Zabrinutost zbog pogrešaka, Roditeljska očekivanja, Roditeljska prigovaranja, Sumnja u vlastitu izvedbu i Organiziranost. Ovako predložena struktura perfekcionizma potvrđena je u dijelu istraživanja, dok su drugi nalazi dobili samo 4 faktora, što upućuje na potrebu za daljnjim istraživanjima na različitim uzorcima. Odgovora se na skali Likertova tipa od 5 stupnjeva. Pouzdanost subskala, koja je provjerena koeficijentima unutrašnje konzistencije tipa Cronbach alpha, je zadovoljavajuća $(0,61-0,87) \mathrm{s}$ prosječnim korelacijama među česticama svake subskale 0,30-0,55.

\section{REZULTATI}

U Tablici 2 prikazane su prosječne vrijednosti i raspršenja rezultata na svim ispitivanim varijablama, raspon rezultata i rezultati Shapiro-Wilk testiranja normalnosti distribucije. 
Jelić, K., Neki prediktori depresivnosti u adolescenciji, Klinička psihologija 12 (2019), 1-2, 21-38

Tablica 2. Prosječne vrijednosti i raspon rezultata ispitivanih varijabli $(N=335)$

\begin{tabular}{|c|c|c|c|c|c|c|c|c|}
\hline \multicolumn{2}{|c|}{ Varijabla } & \multirow{2}{*}{$\begin{array}{c}M \\
55,84\end{array}$} & \multirow{2}{*}{$\begin{array}{c}S D \\
15,25\end{array}$} & \multirow{2}{*}{$\begin{array}{c}\text { Min } \\
27\end{array}$} & \multirow{2}{*}{$\begin{array}{l}\text { Max } \\
102\end{array}$} & \multirow{2}{*}{$\begin{array}{c}\text { Raspon } \\
75\end{array}$} & \multirow{2}{*}{$\begin{array}{c}\text { S-W } \\
, 98\end{array}$} & \multirow{2}{*}{$\begin{array}{c}p \\
00006\end{array}$} \\
\hline & SDD & & & & & & & \\
\hline \multirow{6}{*}{$\frac{\vec{a}}{n}$} & Prihvaćanje - majka & 16,85 & 3,23 & 8 & 21 & 13 & ,93 &, 00000 \\
\hline & Prihvaćanje - otac & 15,45 & 3,28 & 7 & 21 & 14 & ,96 &, 00000 \\
\hline & Kontrola - majka & 15,69 & 4,16 & 10 & 29 & 19 & ,92 &, 00000 \\
\hline & Kontrola - otac & 14,98 & 3,99 & 10 & 28 & 18 & ,91 &, 00000 \\
\hline & Odbacivanje - majka & 10,54 & 2,75 & 8 & 20 & 12 &, 83 & ,00000 \\
\hline & Odbacivanje - otac & 11,52 & 3,33 & 8 & 24 & 16 &, 87 & , 00000 \\
\hline \multirow{6}{*}{$\begin{array}{l}\frac{1}{\dot{1}} \\
\dot{\tilde{a}} \\
\dot{\Sigma}\end{array}$} & Zabrinutost zbog pogrešaka & 20,91 & 7,54 & 9 & 45 & 36 & ,96 & 00000 \\
\hline & Organiziranost & 22,56 & 5,92 & 6 & 30 & 24 & ,92 &, 00000 \\
\hline & Roditeljska očekivanja & 12,71 & 4,80 & 5 & 25 & 20 & ,97 &, 00000 \\
\hline & Osobni standardi & 20,87 & 5,74 & 7 & 35 & 28 & ,99 & 03213 \\
\hline & Sumnja u vlastitu izvedbu & 10,81 & 3,61 & 4 & 20 & 16 & ,98 & , 00009 \\
\hline & Roditeljska prigovaranja & 7,83 & 3,15 & 4 & 20 & 16 & ,90 & 00000 \\
\hline
\end{tabular}

$p<, 05$

Konstruktna valjanost MPS-F skale provjerena je faktorskom analizom (metodom zajedničkih faktora) uz varimax rotaciju i Kaiser-Guttmanov kriterij. Dobiveno rješenje upućuje na postojanje 4 faktora, odnosno konačno faktorsko rješenje razlikuje se od načina formiranja rezultata na subskalama. Dominantan faktor zasićen je s čak 18 čestica skale, što znatno otežava njegovu interpretaciju, ali prema inspekciji čestica moglo bi se zaključiti kako se radi o negativnom perfekcionizmu (čestice iz subskale Roditeljsko prigovaranje, Zabrinutost zbog pogreške i Sumnja u vlastitu izvedbu). Drugi faktor zasićen je svim česticama sa subskale Organiziranost, uz još dvije čestice čiji su koeficijent na samoj granici značajnosti. Treći dobiveni faktor odnosi se na Roditeljska očekivanja, uz dvije čestice iz subskale Roditeljsko prigovaranje, dok se četvrti sastoji od čestica iz subskale Osobni standardi. Pojedine čestice ne koreliraju značajno ni s jednim od faktora.

\section{Ispitivanje razlika s obzirom na dob i spol}

Prvi istraživački problem odnosio se na utvrđivanje razlika u dimenzijama perfekcionizma, procjene stilova roditeljskog odgoja i depresivnosti adolescenata te je u tu svrhu upotrijebljena višesmjerna analiza varijance s post hoc testiranjem. Tablica 3 prikazuje dobivene rezultate prema dobi i spolu sudionika.

Obradom rezultata utvrđeno je postojanje značajnog utjecaja varijabli spol i dob na razinu depresivnosti mjerene Skalom depresivnosti za djecu i adolescente. 
Tablica 3. Rezultati testiranja značajnosti razlika u prosječnim rezultatima na odabranim varijablama s obzirom na dob i spol sudionika $(N=335)$

\begin{tabular}{|c|c|c|c|c|c|c|c|}
\hline \multirow{2}{*}{ Var } & & \multicolumn{3}{|c|}{ DOB } & \multicolumn{3}{|c|}{ SPOL } \\
\hline & & $d f$ & $F$ & $p$ & $d f$ & $F$ & $p$ \\
\hline & SDD & 3 & 4,217 &, $006^{* *}$ & 1 & 21,701 &, $000 * *$ \\
\hline \multirow{6}{*}{$\frac{\hat{a}}{\tilde{a}}$} & Prihvaćanje - majka & 3 & ,455 & ,714 & 1 & ,409 &, 523 \\
\hline & Prihvaćanje - otac & 3 & ,783 &, 504 & 1 & ,942 & ,332 \\
\hline & Kontrola - majka & 3 & 1,914 &, 127 & 1 &, 134 &, 715 \\
\hline & Kontrola - otac & 3 & 2,715 &, $045^{*}$ & 1 & 3,620 &, 058 \\
\hline & Odbacivanje - majka & 3 & 1,809 & ,145 & 1 &, 013 & ,910 \\
\hline & Odbacivanje - otac & 3 & 1,807 &, 146 & 1 & 1,514 &, 219 \\
\hline \multirow{6}{*}{$\begin{array}{l}\frac{1}{1} \\
\dot{n} \\
\dot{\Sigma}\end{array}$} & Zabrinutost zbog pogrešaka & 3 & 2,609 &, 052 & 1 & ,139 & ,709 \\
\hline & Organiziranost & 3 & 1,148 & ,330 & 1 & 12,992 &, $000 * *$ \\
\hline & Roditeljska očekivanja & 3 & ,768 &, 515 & 1 & 8,328 &, $004 *$ \\
\hline & Osobni standardi & 3 & ,335 & 800 & 1 &, 005 & ,945 \\
\hline & Sumnja u vlastitu izvedbu & 3 & ,931 &, 426 & 1 & 3,501 &, 062 \\
\hline & Roditeljska prigovaranja & 3 & 1,777 &, 151 & 1 & 110 &, 741 \\
\hline
\end{tabular}



Slika 1. Grafički prikaz prosječnih vrijednosti rezultata na Skali depresivnosti za djecu i adolescente s obzirom na dob i spol sudionika 
Međutim, interakcijski efekt navedenih varijabli nije se pokazao značajnim. Konkretno, utvrđeno je kako sudionici u dobi od 15 godina izvještavaju o statistički značajno nižim razinama depresivnosti nego sudionici u dobi od 18 godina te kako dječaci izvještavaju o značajno nižim razinama depresivnosti nego djevojke, kao što je prikazano na Slici 1.

Što se tiče ostalih rezultata, analiza varijance uglavnom nije utvrdila značajne efekte dobi i spola. Postoje određene iznimke, kao što je dimenzija Kontrola od strane oca kod koje analiza varijance upućuje na razlike s obzirom na dob, gdje je najviša prosječna vrijednost dobivena na šesnaestogodišnjacima $(M=16,05)$. Dio objašnjenja odnosi se na strukturu uzorka, odnosno činjenicu da je u toj kategoriji bilo najviše učenika te da su oni bili podjednako zastupljeni prema dobi. Također, zbog potrebe adolescenata da ostvare samostalnost otprilike $\mathrm{u}$ istom periodu dolazi do sukoba s roditeljima u kojima mladi testiraju granice slobode i upravo su tada mogući najveći sukobi unutar obitelji.

Na dimenziji Organiziranost djevojke su postizale značajno više rezultate $(\mathrm{M}=$ 23,43), dok su dječaci pokazali veće vrijednosti na dimenziji Roditeljska očekivanja $(\mathrm{M}=13,88)$. To je povezano s rodnim tipiziranjem gdje se kod djevojaka veći naglasak stavlja na prosocijalno ponašanje, a kod dječaka na uspjeh i status.

Utvrđivanje odnosa među varijablama

Rezultat na Skali depresivnosti za djecu $i$ adolescente značajno je povezan i s ostalim varijablama, uz iznimku dimenzije Organiziranost iz MPS-F, stoga je opravdano očekivati doprinos navedenih varijabli u objašnjavanju depresivnosti kod adolescenata te u idućem koraku provjeriti koliko iznosi ukupna varijanca koju možemo objasniti njihovim zajedničkim utjecajem. Podaci su prezentirani u Tablici 4.

Doprinos perfekcionizma i stilova odgoja

tumačenju depresivnosti kod adolescenata

Rezultati hijerarhijske regresijske analize pokazuju da postoji inkrementalna valjanost dodavanja varijabli iz Skale percipiranog roditeljskog ponašanja te faceta Multidimenzionalne skale perfekcionizma, kao što je prikazano u Tablici 5.

Model koji sadrži isključivo demografske varijable (spol i dob) objašnjava ukupno 8,2\% varijance depresivnosti adolescenata i to predstavlja značajno povećanje efikasnosti prognoziranja. Uvrštavanjem varijabli roditeljskoga ponašanja objašnjeno je ukupno $24,8 \%$ varijance depresivnosti, ali od ukupno 6 varijabli koje se tiču roditeljskoga stila jedino se Kontrola (od strane majke i oca) pokazala kao značajan prediktor, moguće zbog povezanosti psihološke kontrole s negativnim afektima i 


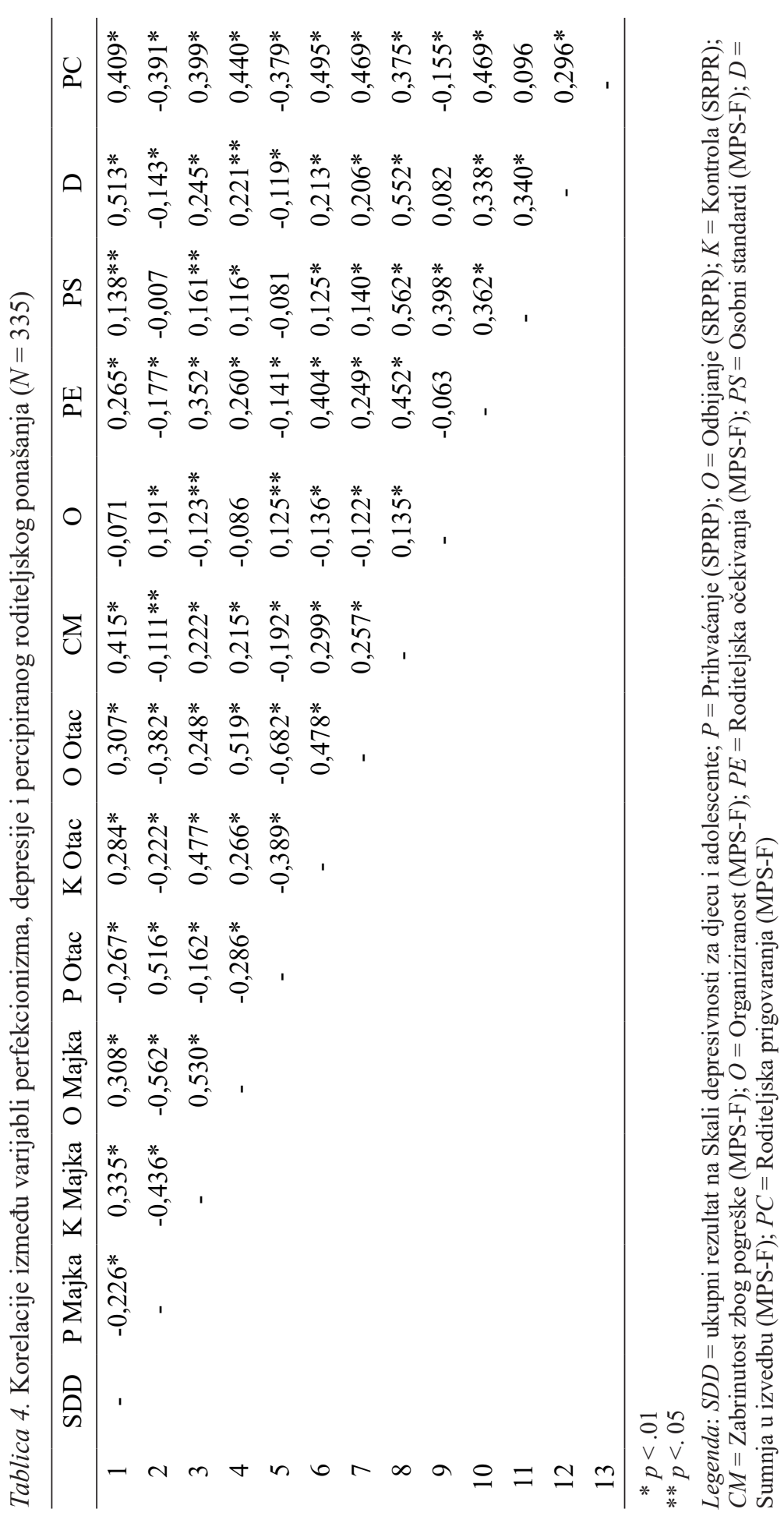


Tablica 5. Prikaz promjene u količini objašnjene varijance upotrebom hijerarhijske regresijske analize

\begin{tabular}{ccccccc}
\hline Razina & $R$ & $R^{2}$ & $R_{\mathrm{c}}{ }^{2}$ & $\Delta R^{2}$ & $F$ & $p$ \\
\hline 1 &, 296 &, 087 &, 082 &, 087 & 15,826 &, 000 \\
2 &, 516 &, 266 &, 248 &, 179 & 13,279 &, 000 \\
3 &, 678 &, 459 &, 436 &, 193 & 19,043 &, 000 \\
\hline
\end{tabular}

Legenda: $R$ - koeficijent multiple korelacije, $R^{2}$ - koeficijent multiple determinacije, $R_{c}^{2}$ - korigirani koeficijent multiple determinacije, $\Delta R^{2}$ - veličina promjene koeficijenta determinacije, $F$ - veličina $\mathrm{F}$ omjera za tu promjenu koeficijenta multiple determinacije, $\mathrm{p}$ - razina rizika.

Tablica 6. Prikaz parcijalnih koeficijenata dobivenih metodom hijerarhijske regresijske analize

\begin{tabular}{|c|c|c|c|c|c|c|}
\hline & $B$ & $S P \beta$ & $B$ & $S P \mathrm{~b}$ & $t$ & $p$ \\
\hline Dob & 0,118 & 0,053 & 1,661 & 0,749 & 2,218 & $0,027 *$ \\
\hline Spol & 0,251 & 0,053 & 7,981 & 1,694 & 4,711 & $0,000^{*}$ \\
\hline Dob & 0,100 & 0,049 & 1,405 & 0,686 & 2,048 & $0,041 *$ \\
\hline Spol & 0,268 & 0,050 & 8,547 & 1,582 & 5,403 & $0,000 *$ \\
\hline P majka & 0,005 & 0,069 & 0,025 & 0,325 & 0,078 & 0,938 \\
\hline $\mathrm{K}$ majka & 0,190 & 0,066 & 0,696 & 0,241 & 2,892 & $0,004^{*}$ \\
\hline O majka & 0,081 & 0,072 & 0,452 & 0,400 & 1,130 & 0,259 \\
\hline P otac & $-0,049$ & 0,077 & $-0,228$ & 0,359 & $-0,636$ & 0,525 \\
\hline K otac & 0,124 & 0,063 & 0,474 & 0,240 & 1,976 & $0,049 *$ \\
\hline O otac & 0,136 & 0,080 & 0,621 & 0,364 & 1,704 & 0,089 \\
\hline Dob & 0,116 & 0,042 & 1,631 & 0,595 & 2,740 & $0,006^{*}$ \\
\hline Spol & 0,234 & 0,045 & 7,452 & 1,439 & 5,178 & $0,000^{*}$ \\
\hline P majka & 0,042 & 0,061 & 0,196 & 0,286 & 0,685 & 0,494 \\
\hline $\mathrm{K}$ majka & 0,134 & 0,058 & 0,491 & 0,213 & 2,305 & $0,022 *$ \\
\hline O majka & 0,026 & 0,063 & 0,144 & 0,351 & 0,409 & 0,683 \\
\hline P otac & $-0,061$ & 0,067 & $-0,284$ & 0,313 & $-0,907$ & 0,365 \\
\hline K otac & 0,004 & 0,057 & 0,014 & 0,220 & 0,065 & 0,949 \\
\hline O otac & 0,058 & 0,070 & 0,265 & 0,319 & 0,831 & 0,407 \\
\hline $\mathrm{CM}$ & 0,185 & 0,060 & 0,375 & 0,121 & 3,092 & $0,002 *$ \\
\hline $\mathrm{O}$ & $-0,082$ & 0,048 & $-0,211$ & 0,124 & $-1,696$ & 0,091 \\
\hline PS & 0,011 & 0,054 & 0,034 & 0,171 & 0,201 & 0,841 \\
\hline PE & $-0,100$ & 0,057 & $-0,266$ & 0,152 & $-1,758$ & 0,080 \\
\hline $\mathrm{D}$ & 0,328 & 0,051 & 1,388 & 0,215 & 6,449 & $0,000 *$ \\
\hline $\mathrm{PC}$ & 0,142 & 0,057 & 0,69 & 0,276 & 2,502 & $0,013^{*}$ \\
\hline
\end{tabular}

$* p<, 01$
Legenda: $\beta=$ standardizirani parcijalni regresijski koeficijent, $\mathrm{b}=$ nestandardizirani parcijalni regresijski koeficijent, $t=\mathrm{t}$-test značajnosti veličine parcijalnog regresijskog koeficijenta 
problemima mentalnoga zdravlja djece. Konačno, u trećem bloku analize u regresijski model unesene su facete perfekcionizma te je utvrđena inkrementalna valjanost subskala MPS-F-a. Koeficijent determinacije s uvrštenim trećim blokom varijabli iznosio je $0,436(\mathrm{~F}=19,043, \mathrm{df} 1=6, \mathrm{df} 2=320, \mathrm{p}<, 01)$, spol i dob ostaju značajni prediktori depresivnosti, no varijabla Kontrola od strane oca prestaje biti statistički značajan prediktor, što bi moglo upućivati na to da perfekcionizam ima medijatorsku ulogu u odnosu kontrolirajućeg ponašanja oca i depresivnosti kod adolescenata. Moguće objašnjenje leži u činjenici kako su očevi usmjereniji na postupke discipliniranja i tumačenja društvenih normi, dok su psihološkoj kontroli sklonije majke. Važno je naglasiti kako nemaju sve facete perfekcionizma jednak doprinos, budući da se varijable Osobni standardi, Roditeljska očekivanja i Organiziranost nisu pokazale kao značajni prediktori. Zaključno, dvanaest psiholoških varijabli koje su obuhvaćene u ovom istraživanju, zajedno s osnovnim demografskim varijablama, mogu objasniti dobar dio varijance depresivnosti među adolescentima. Ukupno $43 \%$ objašnjene varijance snažan je argument u smjeru tvrdnje da roditeljski stil i perfekcionizam igraju veliku ulogu u razvoju depresivnosti među adolescentima (Tablica 6).

\section{RASPRAVA}

Sukladno s dosadašnjim spoznajama o depresivnosti kod adolescenata (npr. Vučenović, 2009), nalazi ovog istraživanja potvrđuju veću učestalost pojave depresivnosti kod djevojaka. Slične rezultate po pitanju porasta depresivnosti kod djevojaka u funkciji dobi dobivaju Kurtović i Marčinko (2011) te Vulić-Prtorić i Sorić (2001), koje navode kako je taj trend vidljiv već od osmih razreda. To je posljedica kognitivnog razvoja i razvoja apstraktnog mišljenja, pri čemu kognitivni procesi postaju značajni moderatori negativnog utjecaja stresnih događaja. Alternativno objašnjenje nudi model dijateza-stres, prema kojem je ključna interakcija bioloških i genetskih faktora s jedne strane, te obitelji i kognitivnih faktora s druge strane (Lebedina-Manzoni i Lotar, 2011). Čini se kako žene doživljavaju više stresa i negativnih događaja, osobito u interpersonalnim odnosima. Primjerice, djevojčice su u školi sklonije upotrebljavati relacijsku agresiju i indirektno zlostavljanje, ogovaranje i socijalno isključivanje (Sesar, 2011). Nakon negativnih događaja, djevojke su sklonije samokritičnosti i donošenju negativnih zaključaka o sebi, što može biti svojevrsna spirala k depresivnosti, padu samopoštovanja i tjeskobi.

Dobne razlike u depresivnosti također su potvrđene, gdje stariji sudionici uglavnom pokazuju nešto više razine depresivnosti. Ovakav rezultat je očekivan jer je povezanost negativnih životnih događaja i afekata jača u adolescenciji, stoga je vjerojatno da pod utjecajem povećane osjetljivosti dolazi do porasta depresivnosti (Ge, Conger i Elder, 2001). Drugi razlog krije se u razvoju apstraktnoga mišljenja te zahtjevima postizanja samostalnosti tijekom kojega dolazi do učestalijih sukoba 
s članovima obitelji. Neprikladne kognitivne sheme te sklonost idealizaciji i pretjeranim očekivanjima koji su karakteristični za ovaj životni period, mogu otežati ionako zahtjevan razvojni proces.

Kada je riječ o razlikama na dimenzijama roditeljskog stila odgoja i perfekcionizma, uglavnom nisu dobivene značajne razlike, uz pojedine iznimke. Inicijalno je utvrđeno da na dimenziji Roditeljska očekivanja dječaci postižu značajno više rezultate, dok je kod djevojčica izraženija dimenzija Organiziranosti te se pokazalo kako na dimenziji Kontrole od strane oca postoje određene dobne razlike. Moguće je da su očekivanja roditelja izraženija kod dječaka, jer su ih djevojčice internalizirale ranije tijekom djetinjstva, što potvrđuje izraženija dimenzija organiziranosti koja nije značajno povezana s depresivnosti i taj nalaz ide u prilog tvrdnji kako je organiziranost jedna od adaptivnih faceta perfekcionizma.

Rezultati na Skali depresivnosti za djecu i adolescente dosljedno su povezani s dimenzijama roditeljskog odgoja koje mjeri Skala percepcije roditeljskog ponašanja. Depresivnost je u negativnoj korelaciji s prihvaćanjem od strane majke i oca, dok pozitivno korelira s dimenzijama kontrole i odbacivanja kod oba roditelja. Psihološka kontrola i roditeljsko odbacivanje glavni su rizični faktori koje povezujemo s pojavom depresije kod djece i adolescenata. Primjerice, Vulić-Prtorić (2002) ističe povezanost različitih aspekata internaliziranih problema s percepcijom odbacivanja od strane roditelja.

Osim dimenzija roditeljstva, značajne korelacije dobivene su između Skale depresivnosti za djecu $i$ adolescente te nekih dimenzija perfekcionizma na MPS-F skali. Posebno se ističe povezanost s faktorima Sumnja u izvedbu, Zabrinutost zbog pogrešaka i Roditeljsko prigovaranje. Bespomoćnost u kontroli željenih ishoda nalazi se u osnovi depresije. Budući da se perfekcionisti užasno boje pogrešaka i neodobravanja drugih, često se osjećaju ranjivo i bespomoćno, stoga je dobivena povezanost očekivana.

Perfekcionizam kod adolescenata povezan je s problemima psihološke prilagodbe i različitim poremećajima. No, ta se povezanost često odnosi samo na dimenziju perfekcionističkih briga (Stoeber i Rambow, 2007) koja korelira s neuroticizmom, neučinkovitim strategijama suočavanja i depresijom (Stoeber i Otto, 2006). Lebedina-Manzoni i Lotar (2011) potvrđuju kako depresija i maladaptivni perfekcionizam zajedno dijele čak $27 \%$ varijance i to uz kontrolu ostalih medijatorskih varijabli. Noble, Ashby i Gnilka (2014) također su utvrdili povezanost maladaptivnog perfekcionizma i depresije, uz medijatorski utjecaj strategija suočavanja sa stresom, dok Kurtović (2013) upućuje na to da dimenzije zabrinutosti, sumnje i roditeljskog pritiska, u kombinaciji s podrškom prijatelja i profesora, mogu objasniti 34\% varijance depresivnosti.

Medijatorske varijable su promjenjive pod utjecajem drugih nezavisnih varijabli, a isto tako utječu na zavisne varijable, odnosno u određenom dijelu tumače utjecaj jedne varijable na drugu (Kurtović i Živčić-Bećirević, 2011). Zbog značajnih 


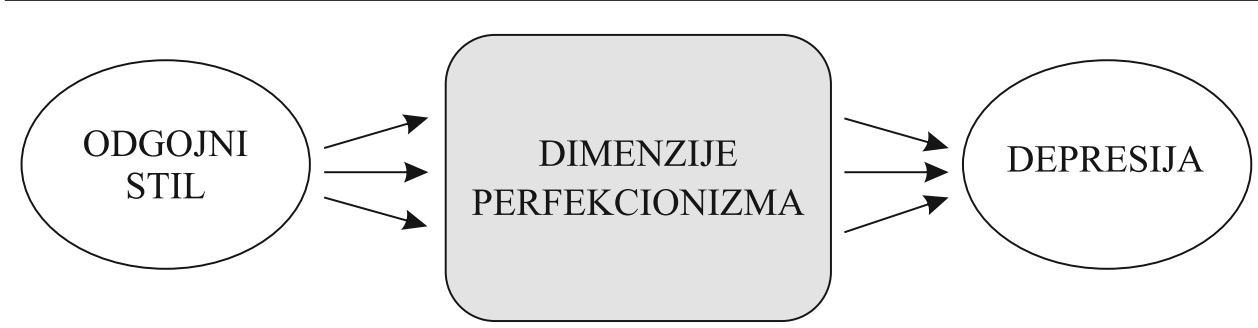

Slika 2. Pretpostavljeni medijatorski model povezanosti roditeljskog odgojnog stila i depresivnosti

povezanosti dimenzija roditeljstva, perfekcionizma i depresivnosti, opravdano je bilo očekivati medijatorski utjecaj (Slika 2).

Prethodna istraživanja uglavnom nisu uključivala zajednički utjecaj dimenzija perfekcionizma i odgojnoga stila roditelja na pojavu depresivnosti kod djece i adolescenata, već su proučavane pojedinačne veze navedenih varijabli s depresivnosti. Rezultati hijerarhijske analize dokazuju vrijednost dodavanja varijabli vezanih uz roditeljski stil i perfekcionizam. Značajan doprinos demografskih varijabli očekivan je i dokazan, uz kontrolu kao jedinu od značajnih dimenzija roditeljskoga ponašanja.

Roditelji skloni pretjeranoj kontroli konstantno upućuju suvišne naredbe praćene prijetnjama, a u odgoju se pozivaju na moć i autoritet. Iako stroga disciplina može spriječiti pojavu nepoželjnog ponašanja jer su djeca poslušnija zbog straha od mogućih posljedica, mnogo su češći internalizirani poremećaji poput depresije. Određena razina kontrole u odgoju je poželjna, naročito ako se odnosi na postavljanje jasnih pravila i očekivanja, definiranje odgovornosti te modifikaciju nepoželjnog ponašanja. Međutim, kontrola koju ne prati emocionalna toplina, a naročito korištenje psihološke kontrole, znatno narušava razvoj djece i mladih.

Od svih dimenzija perfekcionizma, Sumnja u izvedbu, Roditeljska prigovaranja i Zabrinutost zbog pogreške najviše koreliraju s depresijom, dok Organiziranost nije značajno povezana, što je očekivano. Može se zaključiti kako su negativni aspekti perfekcionizma, bliski psihološkim konstruktima neuroticizma, brige i anksioznosti, povezani s depresivnim simptomima. Rezultat kojim je objašnjeno čak $43 \%$ varijance depresivnosti među adolescentima dobar je argument u smjeru tvrdnje da roditeljski stil i perfekcionizam igraju veliku ulogu u razvoju depresivnosti među adolescentima. 


\section{ZAKLJUČAK}

Dobne i spolne razlike u depresivnosti potvrđene su i ranijim istraživanjima, tako da se budućnost istraživanja depresivnosti nalazi u istraživanju njezinih korelata i postavljanju medijatorskih i moderatorskih modela. Rezultati upućuju na zaključak kako postoji medijatorski utjecaj perfekcionizma između očeva odgojnog stila i depresivnosti kod adolescenata. Dakle, u slučaju kada je kontrola roditelja snažna, osobe će biti podložnije razvoju određenih psihopatoloških fenomena, u ovome slučaju depresivnosti.

No, iako utjecajna, perfekcionizam zasigurno nije jedina medijatorska varijabla koja dokazano posreduje nastanku depresivnosti. Postoji čitav niz drugih intervencijskih varijabli, primjerice percepcija moranja (Ellis, 2002), zatim psihološke varijable poput strategija suočavanja sa stresom te osobina ličnosti i percipirane kvalitete vršnjačkih odnosa. Dodatno, moguće je kvalitativnim dijelom obuhvatiti podatke o ranim životnim iskustvima koja bi upućivala na rizične faktore za razvoj depresivnosti.

Uz sve navedeno, potrebno je provjeriti hipoteze o učenju modeliranjem kada je u pitanju razvoj perfekcionizma, budući da Camadan (2010) navodi kako se perfekcionizam kod djevojaka može dobro predvidjeti na osnovi perfekcionizma majki. Moguće je povećati valjanost procjena roditeljskoga stila odgoja korištenjem nekoliko različitih metoda ili izvora procjene roditeljskog ponašanja. Takve procjene mogu biti pod utjecajem trenutačnog raspoloženja ili pamćenja. Naime, retrospektivna sjećanja mogu se iskriviti kako bi postala kongruentna s nečijim pogledom na vlastitu osobnost ili pak kako bi podržali sliku odnosa kakvog trenutačno imamo, što je naročito problematično tijekom adolescencije, stoga dobivene rezultate valja interpretirati uz oprez.

Ograničenja istraživanja, a slijedom toga $\mathrm{i}$ interpretacije dobivenih rezultata, odnose se na određena metodološka pitanja (neizjednjačavanje uzorka po spolu, korištenje mjera samoizvještaja te uključivanje subkliničkih populacija). Potrebno je utvrditi kako ekstremno negativna ponašanja od strane roditelja utječu na pojavu kliničkih simptoma depresije te koliki je njihov jedinstveni doprinos za razumijevanje fenomenologije depresivnosti.

\section{LITERATURA}

Američka psihijatrijska udruga (2006). DSM-5: Dijagnostički i statistički priručnik za duševne poremećaje (2006). Jastrebarsko, Naklada Slap.

Begić, D. (2014). Psihopatologija, 2. izdanje. Zagreb, Medicinska naklada.

Belavić, I. (2006). Povezanost perfekcionizma, anksioznosti i depresivnosti kod djece. Filozofski fakultet u Zagrebu, Diplomski rad.

Berk, L. (2007). Psihologija cjeloživotnog razvoja. Jastrebarsko, Naklada Slap. 
Camadan, F. (2010). Predicting the students' perfectionism from their parents' perfectionism. Procedia - Social and Behavioral Sciences, 2, 4260-4265.

Chang, E. C. (2000). Perfectionism as a predictor of positive and negative psychologicaloutcomes: Examining a mediation model in younger in older adults. Journal of Counseling Psychology, 47, 18-26.

DiBartolo, P. M., Yen Li, C. i Frost, R. O. (2008). How do the dimensions of perfectionism relate to mental health? Cognitive Therapy \& Research, 32 (3), 401-417.

Ellis, A. (2002). The role of irrational beliefs in perfectionism. U G. L. Flett i P. L. Hewitt (ur). Perfectionism: Theory, Research, and Treatment (219-220). Washington DC: American Psychological Association.

Flett, G. L., i Hewitt, P. L. (2002). Perfectionism: Theory, research, and treatment. Washington, American Psychological Association.

Frost, R. O., Marten, P., Lahart, C. i Rosenblate, R. (1990). The dimensions of perfectionism. Cognitive Therapy and Research, 14, 449-468.

Ge, X., Conger, R. D. i Elder, G. H. (2001), The relation between puberty and psychological distress in adolescent boys. Journal of Research on Adolescence, 11 (1), 49-70.

Hewitt, P. L., i Flett, G. L. (1991). Perfectionism in the self and social contexts: Conceptualization, assessment, and association with psychopathology. Journal of Personality and Social Psychology, 60(3), 456-470.

Hwang, P. i Nilsson, B. (2000). Razvojna psihologija: od fetusa do odraslog. Filozofski fakultet Sarajevo.

Hrvatski zavod za javno zdravstvo (2018): Mentalni poremećaji u Republici Hrvatskoj. Zagreb: HZJZ.

Jin, L. (2014). Don't worry, I am fine: a qualitative analysis of family communication and depression in chinese international students in the US. Master Thesis. Open Access Theses. 195

Kurtović, A. (2013). Odnos perfekcionizma i socijalne podrške s anksioznošću i depresivnošću kod studenata. Medica Jadertina, 43(4), 189-200. Preuzeto s https://hrcak.srce. $\mathrm{hr} / 113420$.

Kurtović, A. (2012). Uloga obitelji u depresivnosti adolescenata. Klinička psihologija, 5(12), 37-58. Preuzeto s https://hrcak.srce.hr/158521.

Kurtović, A. i Marčinko, I. (2011). Spolne razlike u atribucijama negativnih i pozitivnih događaja te depresivnim simptomima. Psihologijske teme, 20(1), 1-24. Preuzeto s https:// hrcak.srce.hr/68679.

Kurtović, A. i Živčić-Bećirević, I. (2011). Uloga svakodnevnih negativnih događaja u depresivnosti adolescenata. Društvena istraživanja, 21(3), 671-691.

Lebedina-Manzoni, M. i Lotar, M. (2011). Simptomi depresivnosti i samoorijentirane kognicije. Psihologijske teme, 20(1), 27-45.

Macuka, I. (2008). Skala percepcije roditeljskog ponašanja - SPRP. U Penezić Z. (ur.), Zbirka psihologijskih skala i upitnika IV. Sveučilište u Zadru, str. 23-35.

Noble, C. L., Ashby, J. S. i Gnilka, P. B. (2014). Multidimensional perfectionism, coping and depression: Differential prediction of depression symptoms by perfectionism type. Journal of College Counseling, 17, 80-94. 
Oros, L., Iuorno, O. i Serppe, M. (2017). Child Perfectionism and its Relationship with Personality, Excessive Parental Demands, Depressive Symptoms and Experience of Positive Emotions. The Spanish Journal of Psychology, 20, 1-13. DOI:10.1017/sjp.2017.9.

Parker, W. D. i Adkins, K. K. (1995) Perfectionism and the gifted, Roeper Review, 17(3), 173-175, DOI: 10.1080/02783199509553653.

Sander, J. B. i McCarty, C. A. (2005). Youth depression in the family context: familial risk factors and models of treatment. Clinical child and family psychology review, 8(3), 203-219. https://doi.org/10.1007/s10567-005-6666-3

Seligman, M. (2006). Naučeni optimizam. Zagreb, IEP d.o.o.

Seligman, M. (2005). Optimistično dijete. Zagreb, IEP d.o.o.

Sesar, K. (2011). Obilježja vršnjačkog nasilja. Ljetopis socijalnog rada, 18(3), 497-526.

Shafran, R., Cooper, Z. i Fairburn, C.G. (2002). Clinical perfectionism: A Cognitive behavioural analysis. Behaviour Research and Therapy, 40(7), 773-791.

Stoeber, J. i Otto, K. (2006). Positive conceptions of perfectionism: Approaches, evidence, challenges. Personality and Social Psychology Review, 10, 295-319.

Stoeber, J. i Rambow, A. (2007). Perfectionism in adolescent school students: Relations with motivation, achievement, and well-being. Personality and Individual Differences, 42(7), 1379-1389.

Stoeber, J., Otto, K. i Dalbert, C. (2009). Perfectionism and the Big Five: Conscientiousness predicts longitudinal increases in self-oriented perfectionism. Personality and Individual Differences, 47(4), 363-368, https://doi.org/10.1016/j.paid.2009.04.004.

Vučenović, D. (2009). Emocionalna inteligencija, stilovi roditeljskog odgoja i depresivnost kod adolescenata. Neobjavljeni magistarski rad, Filozofski fakultet, Zagreb

Vulić-Prtorić, A. (2002). Obiteljske interakcije i psihopatološki simptomi u djece i dolescenata. Suvremena psihologija, 5(1), 31-37.

Vulić-Prtorić, A. (2003). Priručnik za skalu depresivnosti za djecu i adolescente. Jastrebarsko, Naklada Slap.

Vulić-Prtorić, A. (2004). Depresivnost u djece i adolescenata. Jastrebarsko, Naklada Slap.

Vulić-Prtorić, A. i Sorić, I. (2001). Taksonomija depresivnosti u djetinjstvu i adolescenciji: razlike i sličnosti s obzirom na spol i dob ispitanika. Medica Jadertina, 31(3-4), 1-22.

Zubčić T. i Vulić -Prtorić A. (2008). Multidimenzionalna skala perfekcionizma (MPS-F), U Penezić Z. (ur.), Zbirka psihologijskih skala i upitnika IV. Sveučilište u Zadru, str. 103-111.

\title{
CERTAIN PREDICTORS OF DEPRESSION IN ADOLESCENCE
}

\begin{abstract}
Depression is a complex psychological construct, interpreted by a large number of factors. The likelihood of experiencing depressive symptoms is twice as high for women. Gender differences in depression begin in late adolescence, when there is an
\end{abstract}


increase in depression in both genders. Such findings were confirmed in this study on a sample of high school students $(\mathrm{N}=335)$ in which depressive symptoms were measured by the Depression Scale for Children and Adolescents (Vulic-Prtoric, 2003).

Depression in the presented sample sought to be explained by a hierarchical model, combining a unique contribution to the variables of adolescents' age, gender, parenting style, and perfectionism. The model thus assumed was able to account for a total of $43 \%$ of the variance in depression in the selected sample.

The authoritative parenting style has been consistently linked to the psychological well-being of children, while the authoritarian style has been linked to a number of internalized issues such as depression. This explains the significant and high correlations between scores on the Perception of parental behavior scale (Macuka, 2008) with depression, but also with measures of perfectionism in the adolescent sample. Perfectionism is defined in terms of setting high standards, with overly critical selfevaluations. In adolescence, performance is emphasized, which, combined with many other changes, makes an individual vulnerable to the development of depression, as indicated by the correlation between scores on the Multidimensional Perfection Scale (MPS-F) and depression.

Key words: adolescence, depression, perfectionism, parenting

Primljeno: 19. 08. 2019. 